\title{
Effect of Different Mulching Materials on the Growth and Yield of Green Bean (Phaseolus vulgaris L.) in Nfonta the Western Highlands of Cameroon
}

\author{
Chi Christopher Tamu ${ }^{1}$, Tatah Eugene Lendzemo ${ }^{2} \&$ Ferdinard Vugheh ${ }^{2}$ \\ ${ }^{1}$ Department of Agricultural Engineering, College of Technology, The University Of Bamenda, P.O.Box 39, \\ Bamenda NWR, Cameroon \\ ${ }^{2}$ Department of Crop Production Technology, College of Technology, The University of Bamenda, P.O.Box 39, \\ Bamenda NWR, Cameroon \\ Correspondence: Tatah Eugene Lendzemo, Department of Crop Production Technology, College of Technology, \\ The University of Bamenda, P.O.Box 39, Bamenda NWR, Cameroon.
}

Received: September 28, 2021 Accepted: November 24, 2021 Online Published: December 13, 2021

doi:10.5539/sar.v11n1p1

URL: https://doi.org/10.5539/sar.v11n1p1

\begin{abstract}
Mulching is a common technique used across the world by farmers to especially conserve soil moisture in vegetable production but farmers in Nfonta and the entire western highlands of Cameroon have not practiced the uses of mulching. In this experiment, a randomized complete block designe with 5 treatments and 3 replications was set up to study the effect of elephant grass, saw dust and white plastic as mulching materials on the growth and yield of green bean (Phaseolusvulgaris L.) in Nfonta. Data was collected on plant height; number of leaves per plants, leaf area index and yield of mature pods per plant. Data was analyzed using one way ANOVA from stat graphics centurion xv and means were separation using the Fischer least significant difference (LSD) test at 95\% confidence interval. Results showed white plastic, and elephant grass mulches to have significantly $(\mathrm{P}<0.05)$ affected the growth and yield of green bean. White plastic mulched plants exhibited the highest growth parameters and subsequently produced the highest yield of 12.00 mature pods per plant with average pod length of $11.97 \mathrm{~cm}$ and average mature pod weight of $4.22 \mathrm{~g}$ compared to the other mulch treatments. There were no significant $(\mathrm{P}>0.05)$ differences in yield of green bean grown with no mulch (control), saw dust mulch and corn stalk mulch. Corn stalk mulched bean plants produced the lowest yield of 7.83 mature pods per plant with average pod length of $9.17 \mathrm{~cm}$ and an average mature pod weight of 2.83 which was not much different from that produced by the control. These results call for more investigations to the potentials of white plastic as best mulch material for achieving optimum green beans yield in Nfonta and the entire western highlands of Cameroon.
\end{abstract}

Keywords: mulch, green beans, white plastic, saw dust, corn stalk, elephant grass

\section{Introduction}

Green bean (Phaseolus vulgaris L.) plant also known as Snap beans, bush beans or string beans is an annual legume grown for its tender green pods. Due to their richness in protein, low caloric, no fat, zero sodium and low cholesterol contents, they count among important vegetable crops in the world (FAO, 2020; Freytag and Debouck, 2002; Porch et al., 2013) including Cameroon. Based on FAOSTAT, Cameroon green beans production has increased steadily from the year 2000 through to the year 2019. The increase has been observed in total area harvested as well as in the per hectare yield. The statistics shows that Cameroon produced about 3.6 tons of green bean per hectare and this experienced a steady increase throughout to 2019 with about 6.3tons per hectare. The average productivity calculated over the 20years $(2000-2019)$ is about 5 tons per hectare. This is very low as compared to the world average production of $13.2 \mathrm{t} \mathrm{ha}^{-1}$ as reported by FAO, 2012.

Their nutritional value is further enhanced by their richness in beta-carotene, fiber, potassium, calcium, and phosphorus. In the Grass fields of Cameroon Snap bean is commonly mixed with minced meat, carrots, bell pepper and white rice to make a popular dish called gelof rice which is highly cherish in many ceremonial events. Besides food security, research has shown that adoption of green beans as an alternative crop can boost the family income of poor smallholder farmers compared to other conventional vegetables (Beshir, 2015, CIAT, 2006; Food and Agriculture Organization, 2011, Ramirez et al., 2011, Kalima, 2013). 
The shallow rooting depth of bean plants poses problems of especially post emergence cultivation for weed management (Widuri et al., 2017).Since one of the benefits of mulching is weed suppression, mulching green beans can help reduce labour requirement on weed management as well as avoid problems of damaging the shallow roots especially during the first weeding. Green beans use about the same amount of water on a weekly basis as other vegetables, but their relatively shallow rooting depth coupled with short growing period expose them high to risk of yield loss if dry spells occur as is the case during the dry season in Nfonta and the entire western highlands of Cameroon.

Climatically snap beans are warm season crops and hence very sensitive to frost. Having optimum temperature for plant growth set at $29^{\circ} \mathrm{C}$, temperature above $32^{\circ} \mathrm{C}$ is devastating to yield as this cause blossoms to drop and ovules to abort while surviving pods become fibrous as well malformed. The dry season do not pose a problem of temperature in Nfonta and the entire western highlands of Cameroon, but the dry harmattan winds and high solar radiation increases the evapotranspiration across farms in the whole region. This increases soil water loses such that the farmer's main problem is how to conserve soil moisture.

Although green beans can perform well in many kinds of soils, best yields are obtained in well-drained, clay loam soil, rich in organic matter and with $\mathrm{pH}$ ranging from5.5 to 7.5. Snap beans require a constant supply of moisture during the growing season and water deficiency or stress, especially during the blossom to pod set period, has been demonstrated to cause blossoms and pods drop, resulting in a poor-quality crop and reduced yields. Also, excess water at any time during growth has been shown to increase the plant's susceptibility to root rot infection, which also can reduce yields. Soil water management is therefore very critical to achieving commercially acceptable high yields in green beans cultivation. This goes $h$ and in hand with managing soil fertility, pest pressure and the quality of seeds as well as adaptability of variety used.

Cameroons western highlands are a tropical highland with two distinct dry and rainy seasons (Molua and Lambi, 2007) which makes it vulnerable to water deficit especially in the dry season when green vegetables becomes a rarity. Farmers resort to diverse methods to satisfy the green vegetable demands of the population. Common methods used by farmers here include the use of manual watering cans, fallowing and the lawless but dangerous exploitation of the few vital wetlandswhich has intensified recently due to demographic pressure and the increasing demand for year round market gardening (Nyambod, 2010; Tita et al., 2011). Mulching is apparently a highly neglected method among farmers in Nfontadespite abundance availability of natural grasses like elephant grass, Thatch grass etcthat could serve as cheap organic mulch materials. This may be as a result of lack of knowledge by farmers or lack of explicit government policies that promote soil and water management as an agricultural adaptation practice (Unique-Kulima/GIZ, 2020). The objective of this study was to select a cheap but effective mulching material among elephant grass, saw dust, white plastic and corn stalk which are very readily available in Nfonta and the entire western highlands of Cameroon.

\section{Material and Methods}

\subsection{Description of Research Site}

This research was carried out at Nfonta seed multiplication and experimentation farm of the Cameroon government Institute of Agriculture for development known by its French acronym as IRAD. It is located in the Western Highlands Agro- ecological Zone covering the North West and West Administrative regions of Cameroon. Nfonta is a generally level location at latitude $6^{\circ}$ north of the Equator and about $1250 \mathrm{~m}$ above sea level and with clay loam soil which favours the cultivation of crops such as maize, legumes, vegetables and Irish potatoes.

Nfonta is characterized mainly by two seasons, the rainy and dry season in which the raining season begins in mid-march and ends in mid-November while the dry season covers the rest of the year. The temperatures are usually slightly cold with an average minimum and maximum of 18 and $28^{\circ} \mathrm{C}$ respectively. It has an average humidity of $75 \%$ which drops to $52 \%$ in the rainy and dry season. It has an annual rainfall of $2230 \mathrm{~mm} / \mathrm{annum}$ uniformly distributed from mid-march to mid-November with the highest peak of $380 \mathrm{~mm}$ occurring in the month of July and August.

\subsection{Experimental Materials and Experimental Design}

Quality green beans seeds and experimental plot were obtained from the station manager. The variety used was a dwarf variety called Cora and imported from a French Company called Technisem. The plot was cleared using a manual machete and hoed and ridged using a hand hoe commonly used by local farmers. Appropriate fine Seed beds were prepared using a manual farm rake. The entire prepared land was divided into three blocks with each block measuring $7 \times 3 \mathrm{~m}$ and a $1 \mathrm{~m}$ distance between blocks. This gave a total experimental area of $117 \mathrm{~m}^{2}$. Each 
block was further divided into five plots with one treatment per plot. Each plot measures $3 \times 1 \mathrm{~m}$ and a $0.5 \mathrm{~m}$ distance between plots. The final experimental design was a randomized complete block design (RCBD) with five treatments and three replications giving a total of 15 plots in the experimental area. A border line of $1 \mathrm{~m}$ was allowed all-round the experimental site and planted with maize.

\subsection{Acquisition, Preparation and Application of Treatments (Mulches)}

\subsubsection{Acquisition, Preparation and Application of Elephant Grass Mulch}

Elephant grass was harvested from IRAD's experimental farm at Nfonta using a machete. During harvesting, only the leaves were selected for use. The grass was then chopped into small sizes to ensure uniform application. It was then spread over the necessary plot making sure that it was at least $1 \mathrm{~cm}$ thick.
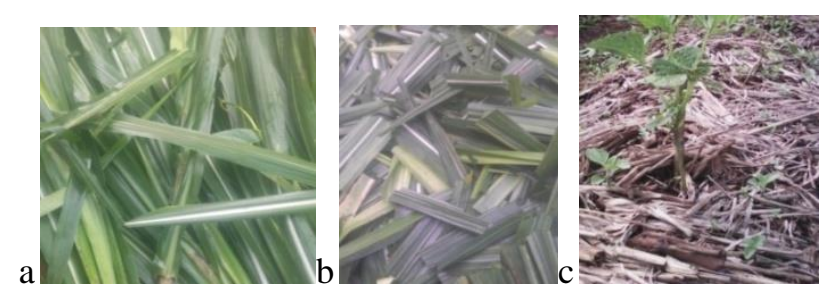

Figure 1. Elephant grass mulch; a) harvested mulch, b) prepared mulch ready for application and c) mulch on ridges with crop

\subsubsection{Acquisition, Preparation and Application of Saw Dust Mulch}

Saw dust was obtained from local carpenters at Nfonta and an application of $2 \mathrm{~kg} / \mathrm{m}^{2}$ was done. This gave a total of $6 \mathrm{~kg}$ of saw dust per plot. Before applying the saw dust, the plot was pecked and saw dust was not applied to the spots where the seeds were to be planted.

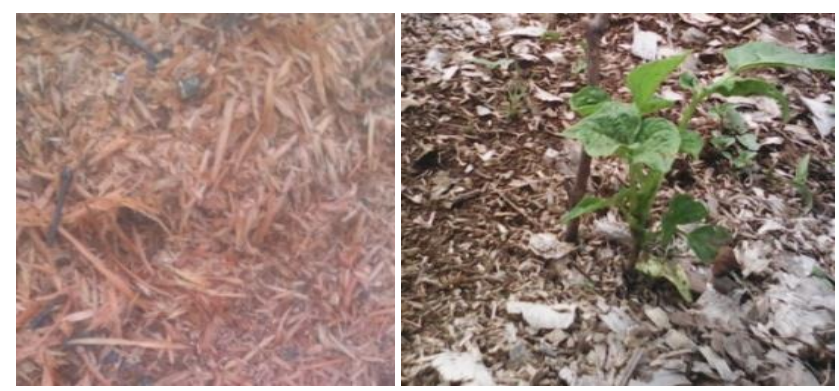

Figure 2. Right saw dust before application; left saw dust Mulched with growing green beans crop

\subsubsection{Acquisition, Preparation and Application of White Plastic Mulch}

White plastic films measuring $1 \times 0.5 \mathrm{~m}$ were bought from Nfonta farmers market and washed with sterile solution. A razor blade was used to open holes on the plastic in the spots where seeds were planted. This was done in order to prevent the plastic from impeding the shooting of the seeds once they germinated.

a)

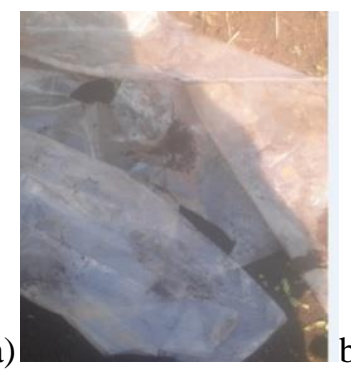

b)

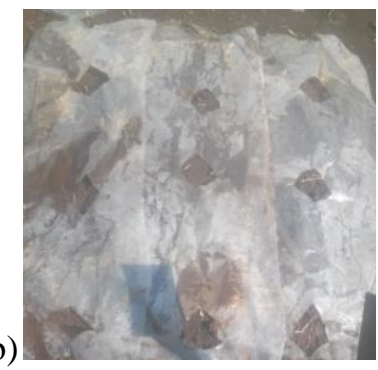

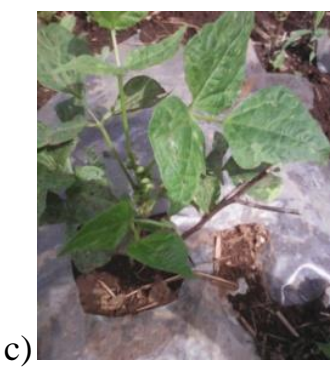

Figure 3. White plastic mulch a) before application b) applied on the ridges and c) with crop growing 


\subsubsection{Acquisition, Preparation and Application of Corn Stalks}

Corn stalks were harvested from IRAD's experimental farm in Nfonta from maize plants that were grown in the previous season. The corn stalks were chopped into smaller sizes using a machete. Chopped corn stalks were put inside a bag and $18 \mathrm{~kg}$ were weighed out using a scale balance. Six (6) $\mathrm{kg}$ was applied to each plot. The chopped corn stalks were then uniformly arranged on the surface of the various plots.
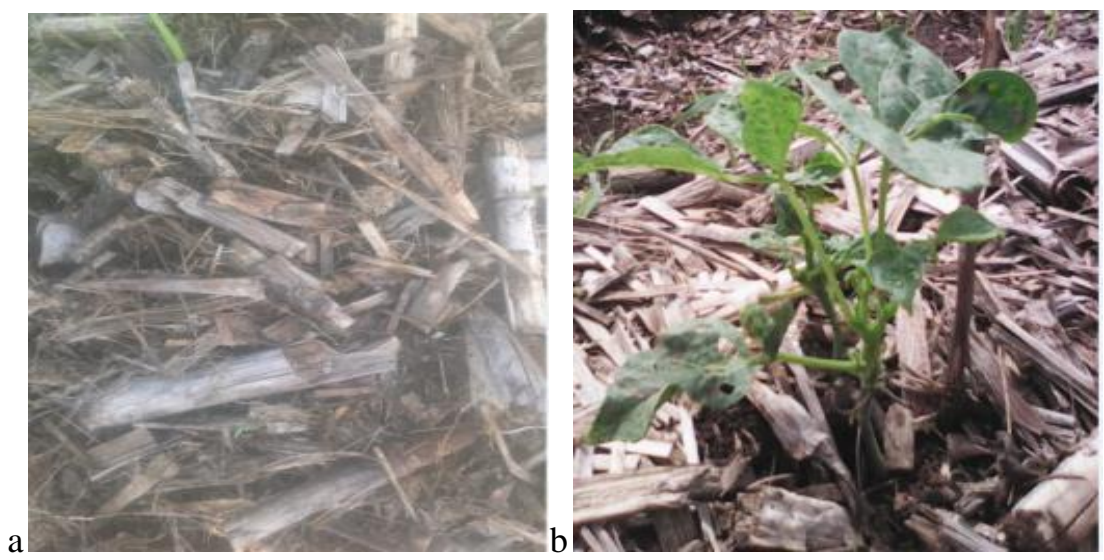

Figure 4. Prepared corn stalk mulch on ridges and $b$ mulch with crop

The resulting experimental treatments were as follows;

- Treatment $1\left(T_{1}\right)=$ Elephant grass at a thickness of $1 \mathrm{~m}$ on each plot gotten from IRAD Farm

- Treatment $2\left(\mathrm{~T}_{2}\right)=$ saw dust at $2 \mathrm{~kg}$ per $\mathrm{m}^{2}$ gotten from local carpenters

- Treatment $3\left(\mathrm{~T}_{3}\right)=$ white plastic measuring $1 \times 0.5 \mathrm{~m}$ per plot/ gotten from Nfonta farmers market

- Treatment $4\left(\mathrm{~T}_{4}\right)=$ corn stalks at $6 \mathrm{~kg} / \mathrm{plot}$ gotten from IRAD farm

- Treatment $5\left(\mathrm{~T}_{5}\right)=$ no mulch $($ control)

They were all applied on the same day as the seeds were planted. The application of saw dust, corn stalk and elephant grass mulches were done at the stations recommended rate of $9050-13,450 \mathrm{~kg}$ per hectare. After applying the mulches on the various plots, the seeds were planted at the stations recommended planting distance of $30 \times 25 \mathrm{~cm}$.

\subsubsection{Miscellaneous Management Activities}

Weed Pest and disease control were planned for all plots to ensure constancy of site factors. Only treatment 5(control) had a significant amount of weeds worthy of controlling. Stem and root soft rot, aphids, and leafhoppers were observed in all treatments and controlled using a fungi champ and broad spectrum insecticide called PYRIGA 480EC respectively.

\section{Data Collection and Analysis}

In a bit to evaluate the effects of mulching material on the growth and yield of green beans, bean plants were cultivated using five different mulch materials- elephant grass, corn stalks, saw dust and white plastic mulch as treatments. A control with no mulch was also used. Data on Plant height; number of leaves per plants, leaf area index and yield of mature pods per plant were collected from the second week starting after planting (2WAP) and continued at two weeks interval. The last was during the eight weeks after planting (8WAP). All the measurements for these parameters were taken from five plants selected randomly from the middle of each plot from each treatment. The value of each parameter per treatment was calculated by using the average from the five randomly selected plants.

\subsection{Data Collection on Plant Height}

Plant height which was considered as the distance from base of the stem to the tip of the plant was measured using a $30 \mathrm{~cm}$ ruler.

\subsection{Data Collection on Number of Leaves per Plant}

Numbers of leaves per plant were taken at $50 \%$ flowering by counting all the healthy leaves from the base to the tip of five randomly selected bean plants from each plot and treatment. 


\subsection{Data Collection on Leaf Area and Leaf Area Index}

A Healthy leaf was selected from each of the five bean plant and the length and width were measured using a $30 \mathrm{~cm}$ ruler. The measurements were used to calculate the leaf area (LA) according to Edje and Ossom, 2009in as follows:

$$
\text { Leaf area }=\text { leaf length } \mathrm{x} \text { width of terminal leaflet } \mathrm{x} 2.88 \text { (correction factor) }
$$

Using the LA results, the leaf area Indices (LAI) were calculated and expressed in Centimeter squares (cm2) using the following formula

$$
\text { Leaf area index }(\mathrm{LAI})=\left[\text { Leaf area }\left(\mathrm{m}^{2}\right) / \text { Ground cover }(\mathrm{m} 2)\right]
$$

\subsection{Data Collection on Yield of Mature Pods per Plant}

Yield and length of mature pods per plant were obtained from harvesting at 8WAP and 10WAP. From each harvest five most succulent pods from each treatment were counted out and weighed using an electronic scale balance. Lengths of the same five pods were taken using a $30 \mathrm{~cm}$ ruler. The average of the values gave the weight and length of the pods from each treatment.
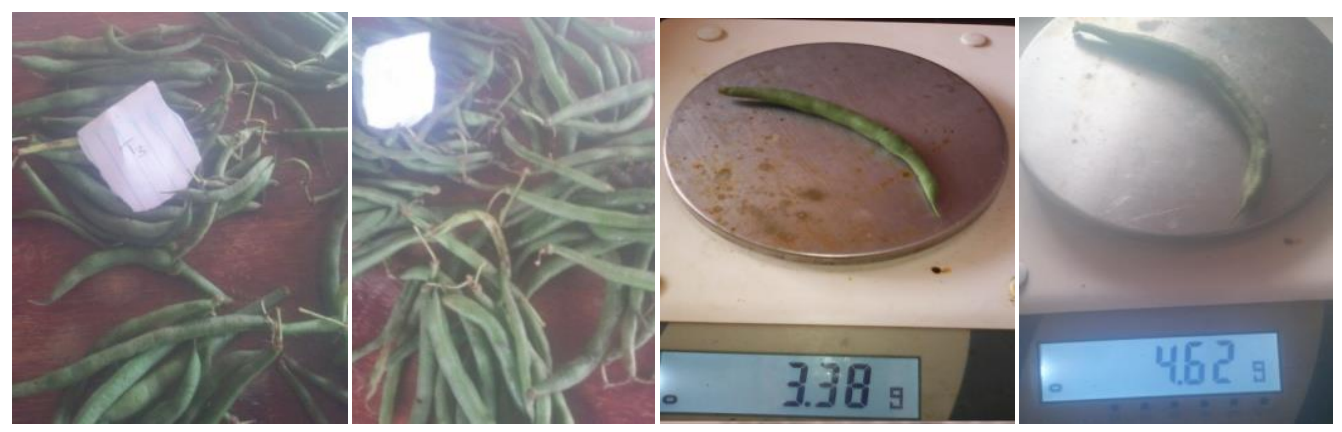

Figure 5. Selected and weighed succulent pods samples

\subsection{Data Analyses}

Data obtained on various growth and yield parameters was analyzed using one way ANOVA from stat graphics centurion $\mathrm{xv}$ and means were separation using the Fischer least significant difference (LSD) test at 95\% confidence interval. Results obtained and their discussions are presented as follows:

\section{Results and Discussions}

\subsection{Effect of Different Mulching Materials on Plant Height}

Table 1 below present the statistical results obtained for effects on beans height when elephant grass, saw dust, white plastic and corn stalk were used separately as mulching material.

Table 1. Effect of different mulching materials on plant height

\begin{tabular}{lllll}
\hline treatments & \multicolumn{4}{l}{ Weeks after planting (WAP) } \\
\cline { 2 - 5 } & $\mathbf{2}$ & $\mathbf{4}$ & $\mathbf{6}$ & $\mathbf{8}$ \\
\hline Elephant grass & $7.57 \pm 0.503^{\mathrm{a}}$ & $8.57 \pm 0.764^{\mathrm{b}}$ & $9.20 \pm 1.212^{\mathrm{cd}}$ & $9.30 \pm 1.212^{\mathrm{b}}$ \\
Saw dust & $6.33 \pm 0.289^{\mathrm{b}}$ & $7.00 \pm 0.6^{\mathrm{d}}$ & $8.27 \pm 1.401^{\mathrm{b}}$ & $8.77 \pm 1.704^{\mathrm{a}}$ \\
White plastic & $7.30 \pm 0.265^{\mathrm{bc}}$ & $9.63 \pm 0.851^{\mathrm{ab}}$ & $11.27 \pm 1.106^{\mathrm{b}}$ & $12.67 \pm 0.802^{\mathrm{a}}$ \\
Corn stalk & $6.70 \pm 0.265^{\mathrm{cd}}$ & $6.87 \pm 0.379^{\mathrm{c}}$ & $7.67 \pm 0.513^{\mathrm{b}}$ & $8.10 \pm 0.361^{\mathrm{b}}$ \\
control & $7.40 \pm 0.656^{\mathrm{cd}}$ & $10.00 \pm 0.2^{\mathrm{c}}$ & $10.67 \pm 0.351^{\mathrm{ab}}$ & $11.17 \pm 0.208^{\mathrm{a}}$ \\
\hline
\end{tabular}

The letters of Alphabets are used to denote significant differences between the means. Means with the same alphabet letters are not significantly different at $\mathrm{P}>0.05$ while Means with different letters are significantly different at $\mathrm{P}<0.05$ according to fishers LSD test. Value \pm denote standard error

According to table 1, at 2WAP, plant height increased across the treatments at all the growth stages no significant difference $\left(P>0.05\right.$ were observed between plants on saw dust $\left(T_{2}\right)$ and white plastic $\left(T_{3}\right)$ mulched and between plants with white plastic $\left(T_{3}\right)$, corn stalk $\left(T_{4}\right)$ and control $\left(T_{5}\right)$. Elephant grass mulched plants $\left(T_{1}\right)$ differed significantly $(\mathrm{P}<0.05)$ from the other treatments during this same 2WAP. Results from the 4WAP, showed no significant differences $(\mathrm{P}<0.05)$ in plant height between plants grown with elephant grass $\left(\mathrm{T}_{1}\right)$ mulched and those grown with white plastic $\left(\mathrm{T}_{3}\right)$ mulch. Plant height under control $\left(\mathrm{T}_{5}\right)$ differed significant from those under 
elephant grass, saw dust and white plastic mulches but no significant difference was observed between plants grown with corn stalk mulch $\left(\mathrm{T}_{4}\right)$.

During the 6WAP period, plant heights grown with elephant grass mulch (T1) differed significantly from those of plants grown on the rest of the treatments.

At 8WAP, while no significant differences were observed between plant heights under control $\left(\mathrm{T}_{5}\right)$ and those under white plastic $\left(\mathrm{T}_{3}\right)$ and saw dust $\left(\mathrm{T}_{2}\right)$ mulches, significant differences were recorded between plants heights under elephant grass mulch and corn stalk mulch. The lowest plant height of $8.10 \mathrm{~cm}$ was recorded by plants under corn stalk mulch during the 8WAP while the highest plant height of $12.67 \mathrm{~cm}$ was recorded by plants under white plastic mulch during the 8WAP. Fig 6 below show variation in plant height recorded with the diverse mulches and the four growth stages.

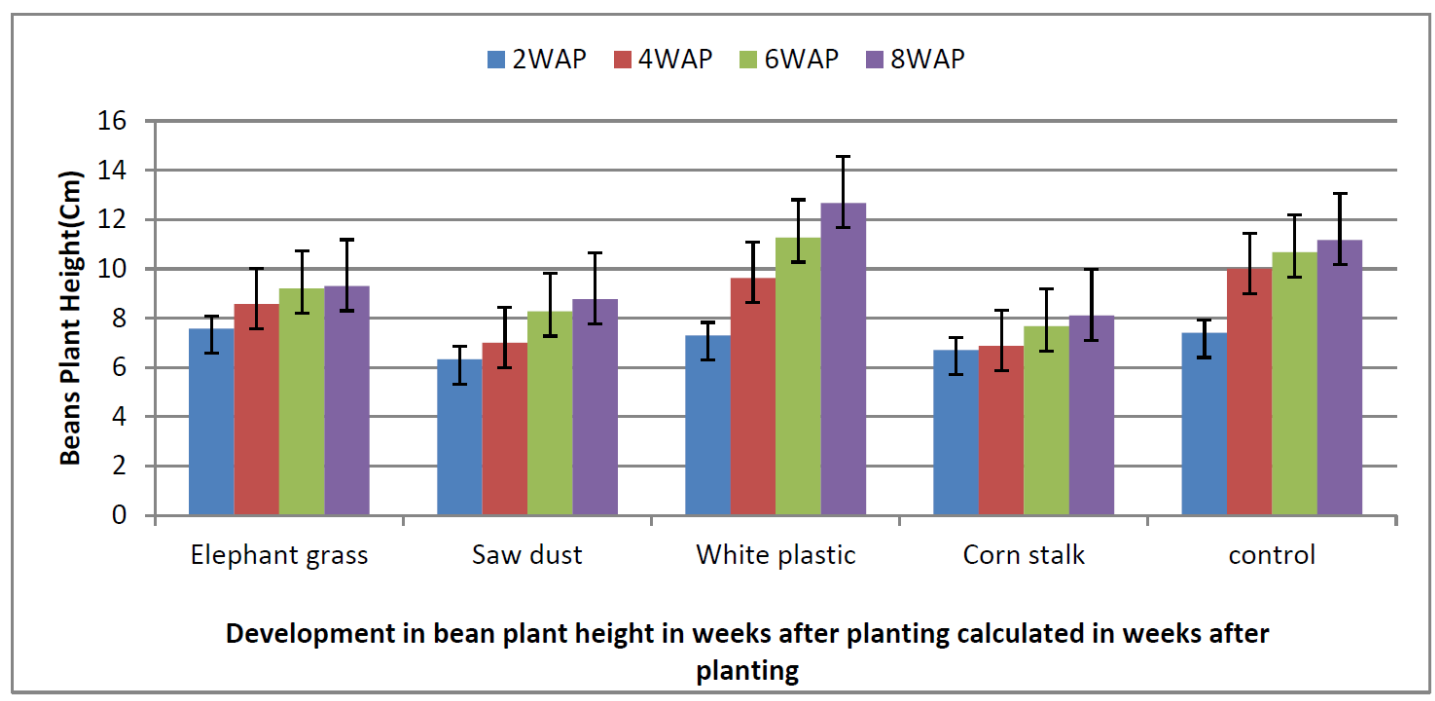

Figure 6. Variation in plant height in the various treatments

The observed lack of any significant difference in height between the corn stalk mulched plants and control plot during the 2WAP can be attributed to the poor decay speed of corn which as a result could not add nutrients to the soil to boost significant plant growth. Poorly decayed corn stalk tends to absorbed soil water thereby depriving plant root zone of ample available water. This may the reason why plant height was lowest $(8.10 \mathrm{~cm})$ when grown with corn stalk mulch. The reason why plants grown with White plastic mulch produced the tallest plant was attributed to the common knowledge that white plastics mulching not only conserve moisture better but also increased soil temperature which gave plants the most favorable condition as reported by Safiullah et al., 1996.

\subsection{Effect of Different Mulching Materials on Number of Leaves per Plant}

Statistical results obtained for effects on number of leaves produced by green bean plants when elephant grass, saw dust, white plastic and corn stalk were used separately as mulching material. In a column, means with the same letters are not significantly different (FMRT 5\%)

Table 2. Effect of different mulching materials on the number of leaves

\begin{tabular}{lllll}
\hline Treatment & \multicolumn{4}{l}{ Weeks after planting } \\
\cline { 2 - 5 } & $\mathbf{2}$ & $\mathbf{4}$ & $\mathbf{6}$ & $\mathbf{8}$ \\
\hline Elephant grass & $7.33 \pm 0.643^{\mathrm{cd}}$ & $9.60 \pm 3.026^{\mathrm{cd}}$ & $12.13 \pm 3.900^{\mathrm{ab}}$ & $11.87 \pm 3.828^{\mathrm{a}}$ \\
Saw dust & $6.33 \pm 0.115^{\mathrm{d}}$ & $9.53 \pm 1.616^{\mathrm{ab}}$ & $12.07 \pm 1.701^{\mathrm{ab}}$ & $11.87 \pm 1.102^{\mathrm{a}}$ \\
White plastic & $10.33 \pm 2.212^{\mathrm{b}}$ & $13.47 \pm 2.082^{\mathrm{b}}$ & $16.40 \pm 3.219^{\mathrm{ab}}$ & $15.13 \pm 3.062^{\mathrm{a}}$ \\
Corn stalk & $6.20 \pm 0.871^{\mathrm{c}}$ & $8.60 \pm 0.917^{\mathrm{d}}$ & $10.40 \pm 0.8^{\mathrm{d}}$ & $10.40 \pm 1.249^{\mathrm{b}}$ \\
control & $8.93 \pm 1.331^{\mathrm{ab}}$ & $12.33 \pm 0.577^{\mathrm{ab}}$ & $13.73 \pm 2.540^{\mathrm{ab}}$ & $15.67 \pm 4.119^{\mathrm{a}}$ \\
\hline
\end{tabular}

The letters of Alphabets are used to denote significant differences between the means. Means with the same alphabet letters are not significantly different at $\mathrm{P}>0.05$ while Means with different letters are significantly different at $\mathrm{P}<0.05$ according to fishers LSD test. Value \pm denote standard error 
From table 2, it can be inferred that while the number of leaves per plants grown with corn stalk mulch $\left(\mathrm{T}_{4}\right)$ did not change, the number of leaves per plant increased from 2WAP to 6WAP for all treatments but dropped at $8 \mathrm{WAP}$ for plants grown with elephant grass (T1) and saw dust $\left(\mathrm{T}_{2}\right)$ mulches. At $2 \mathrm{WAP}$, no significant differences $(\mathrm{P}>0.05)$ were recorded in the number of leaves per plant between plants under control $\left(\mathrm{T}_{5}\right)$ and those grown with white plastic $\left(\mathrm{T}_{3}\right)$ mulch. At $4 \mathrm{WAP}$, the number of leaves per plant in the control plot did not differ significantly $(\mathrm{P}>0.05)$ from that grown with white plastic $\left(\mathrm{T}_{3}\right)$ and saw dust $\left(\mathrm{T}_{2}\right)$ mulches. During the 6WAP period, no significant differences were observed in number of leaves per plant between plants grown under control (T5) and those grown with saw dust (T2) and elephant grass (T1) mulches. Results from the 8WAP showed significant differences $(\mathrm{P}<0.05)$ in number of leaves per plant between plants grown with corn stalk $(\mathrm{T} 4)$ mulch and the rest of the treatments as well as between green bean plants mulched with White plastic and the rest of the treatments. The lowest numbers of leaves per plant were recorded by plants grown with corn stalk $\left(\mathrm{T}_{4}\right)$ mulch and the largest numbers of leaves per plant were recorded by plants grown with the white plastic (T3) mulch. This again may have been because of poor decomposition of corn stalk which prevented the addition of extra available nutrients that subsequently retarded plant growth and the positive water retention of nutrients (due to reduced volatization), moisture and warmth by plastic which provided the root zone with favorable conditions for growth. Tarara, 2009 and Kwambe et al. 2015 both reported that warm roots grew faster and resulted in accelerated plant growth.

\subsection{Effect of Different Mulching Materials on Leaf Area Index}

Presented in table 3 are results of effects of the five mulch treatments on the leaf area indices of green beans plants. In a column, means with the same letters are not significantly different (FMRT 5\%).

Table 3. Effect of different mulching materials on the leaf area index

\begin{tabular}{lllll}
\hline Treatment & \multicolumn{5}{l}{ Weeks after planting } & \\
\cline { 2 - 5 } & $\mathbf{2}$ & $\mathbf{4}$ & $\mathbf{6}$ & $\mathbf{8}$ \\
\hline Elephant grass & $0.20 \pm 0.007^{\mathrm{ab}}$ & $0.25 \pm 0.030^{\mathrm{b}}$ & $0.26 \pm 0.054^{\mathrm{b}}$ & $0.28 \pm 0.101^{\mathrm{ab}}$ \\
Saw dust & $0.18 \pm 0.052^{\mathrm{c}}$ & $0.26 \pm 0.037^{\mathrm{c}}$ & $0.27 \pm 0.065^{\mathrm{c}}$ & $0.29 \pm 0.070^{\mathrm{ab}}$ \\
White plastic & $0.24 \pm 0.034^{\mathrm{b}}$ & $0.34 \pm 0.015^{\mathrm{a}}$ & $0.36 \pm 0.023^{\mathrm{b}}$ & $0.43 \pm 0.007^{\mathrm{a}}$ \\
Corn stalk & $0.15 \pm 0.006^{\mathrm{a}}$ & $0.21 \pm 0.019^{\mathrm{b}}$ & $0.22 \pm 0.019^{\mathrm{b}}$ & $0.19 \pm 0.008^{\mathrm{d}}$ \\
control & $0.25 \pm 0.018^{\mathrm{a}}$ & $0.35 \pm 0.049^{\mathrm{c}}$ & $0.35 \pm 0.011^{\mathrm{a}}$ & $0.39 \pm 0.072^{\text {dd }}$ \\
\hline
\end{tabular}

The letters of Alphabets are used to denote significant differences between the means. Means with the same alphabet letters are not significantly different at $\mathrm{P}>0.05$ while Means with different letters are significantly different at $\mathrm{P}<0.05$ according to fishers LSD test. Value \pm denote standard error

Table 3 shows that with the exception of plants grown with corn stalk (T4) mulch in which the the leaf area index dropped from the 6WAP to the 8WAP, the leaf area index increased across the growth stages for the rest of the treatments. During the 2WAP and 6WAPperiods, Leaf area indices of plants grown with saw dust (T2) mulch were significantly different $(\mathrm{P}<0.05)$ from those of plants grown with the rest of the treatments. During the 8 WAP period, no significant difference $(\mathrm{P}>0.05)$ in the leaf area indices was recorded between plants grown with corn stalk (T4) mulch and those under control (T5). During the 4WAP, 6WAP and 8WAP, the leaf area index of plants grown with saw dust and under control were significantly different $(\mathrm{P}<0.05)$ from those of the other treatments. The lowest leaf area index (0.19) was recorded with plants grown with corn stalk (T4) mulch treatment while the highest $(0.43)$ was recorded by plants grown with the white plastic (T3) mulch treatment. Carmichael et al. (2012.) reported statistically correlation between leaf number and leaf area index. Results of leaf number above were found to be lowest with plants grown with corn stalk mulch and highest with plants under white plastic (T3) mulch.

\subsection{Effect of Different Mulching Materials on the Yield of Green Beans}

Results of effect on yield of green bean plants captured as number of pods, pod length in centimeters and pod weights in grams when grown with elephant grass saw dust, white plastic and corn stalk as mulching materials are presented on table 4 below. In a column, means with the same letters are not significantly different (FMRT $5 \%)$ 
Table 4. Effect of different mulching materials on the yield of green beans

\begin{tabular}{llll}
\hline Treatment & Number of pods & Pod length $(\mathbf{c m})$ & Pod weight (g) \\
\hline Elephant grass & $7.67 \pm 0.877^{\mathrm{a}}$ & $10.07 \pm 0.569^{\mathrm{ab}}$ & $3.65 \pm 1.755^{\mathrm{ab}}$ \\
Saw dust & $8.00 \pm 0.166^{\mathrm{d}}$ & $9.19 \pm 0.551^{\mathrm{c}}$ & $2.83 \pm 1^{\mathrm{c}}$ \\
White plastic & $12.00 \pm 0.165^{\mathrm{c}}$ & $11.97 \pm 4.147^{\mathrm{a}}$ & $4.22 \pm 1.323^{\mathrm{bc}}$ \\
Corn stalk & $7.83 \pm 0.220^{\mathrm{a}}$ & $9.23 \pm 0.585^{\mathrm{bc}}$ & $3.16 \pm 1.041^{\mathrm{bc}}$ \\
Control & $9.50 \pm 0.171^{\mathrm{cd}}$ & $10.40 \pm 0.264^{\mathrm{d}}$ & $3.76 \pm 1.732^{\mathrm{b}}$ \\
\hline
\end{tabular}

The letters of Alphabets are used to denote significant differences between the means. Means with the same alphabet letters are not significantly different at $\mathrm{P}>0.05$ while Means with different letters are significantly different at $\mathrm{P}<0.05$ according to fishers LSD test. Value \pm denote standard error

From this table, the number of pods per plants under control $\left(\mathrm{T}_{5}\right)$ was not significantly different $(\mathrm{P}>0.05)$ from those grown with the white plastic $\left(T_{3}\right)$ and saw dust $\left(T_{2}\right)$ mulch. The smallest number of pods was obtained from plants grown with elephant grass (T1) mulch while the highest were obtained from the plants grown with white plastic $\left(\mathrm{T}_{3}\right)$ mulch.

The pod length from the control $\left(\mathrm{T}_{5}\right)$ plot significantly differed from the rest of the other treatments. Plants grown with saw dust $\left(\mathrm{T}_{2}\right)$ mulch produced the shortest pods $(9.17 \mathrm{~cm})$ while the longest pod $(11.97 \mathrm{~cm})$ were produced by plants grown with white plastic $\left(\mathrm{T}_{3}\right)$ mulch.

No significant differences $(\mathrm{P}>0.05)$ were found between the pod weight of plants from control $\left(\mathrm{T}_{5}\right)$ and those from corn stalk $\left(\mathrm{T}_{4}\right)$, white plastic $\left(\mathrm{T}_{3}\right)$, and the elephant grass $\left(\mathrm{T}_{1}\right)$ mulches. The lightest pods $(2.83 \mathrm{~g})$ were obtained from plants grown with saw dust $\left(\mathrm{T}_{2}\right)$ and the heaviest $(4.22 \mathrm{~g})$ came from plants grown with white plastic $\left(\mathrm{T}_{3}\right)$ mulch.

Pod yield (fresh mass) between plants harvested from white plastic, elephant grass and corn stalk mulches significant differed $(\mathrm{P}<0.05)$ from those obtained from saw dust mulch and control. The highest pod yieldswere obtained from plants grown with elephant grass mulches and the lowest from Saw dust mulch. Based on the fact that only elephant grass leaves were used, one will relate the positive performance of green beans grown with elephant grass as mulch to the easy decay of the leaves which must have added extra available nutrient to the soil. This observation was also made by Anon., 2008. The relatively low pod yields obtained from Saw dust mulch could be related to potential allelopathy effects especially if the saw dust was from Eucalyptus or from pine woods notwithstanding the possibilities that like corn stalks, saw dust could equally soak soil water depriving plants from available water for yield production.

\section{Conclusions and Recommendations}

Mulching was found to boost green beans yield in Nfonta in the western highlands of Cameroon. The difference in effects from using Organic and inorganic was very clear as plastic (inorganic) mulch outperformed all the organic mulches(saw dust, corn stalk, elephant grass) in all the cases considered. White plastic produced the best results in terms of both growth and yield, followed by elephant grass mulch. .These findings are in unison with Quamruzzaman et al, 2021 who reported plastic mulch to have boosted the yields of both fruit and vegetables in an experiment.

- Based on the results of this research, one is tempted to recommend plastic mulch as the solution to combating soil moisture shortages by farmers in Nfonta. Despite the positive outcome, farmers will need to be educated on the adverse effects of plastics as well as be educated about biodegradable plastics which unfortunately are not available, accessible or affordable in Cameroon for now. It is also recommended that producers use the locally available mulching materials. There is hence a need for further research and a sound government policy as to the use of plastics on farms in Cameroon.

- From the study of effects of the four different mulching materials on the yield of green beans in table 4 above, Elephant grass mulch and saw dust despite both being organic were observed produced significantly different number of pods, pod length and pod weights used to measure final bean yield. Similar findings were also made by Jodaugiene et al. 2018 who attributed the differences to the presence of Allelopathic chemicals in saw dust as compared to elephant grass. Saw dust is a highly available and affordable mulching material in the grass field and farmers will easily go for them. Hence a research evaluating the allelochemicals in diverse woods used by local carpenters is highly recommended if farmers in Nfonta are to be encouraged to use saw dust as a cheaply available mulching material. 
- Ajibola et al, 2014 and Teame et al; 2017 both reported improved crop yield in plots mulched with elephant grass which agrees with the findings in this research as can be inferred in fig 4.

- Elephant grass is a common weed along road sides and farms in Cameroon. Recommending this as mulch material for farmers is sustainable as it is cheaply available and accessible and can be managed by ratooning. It will even go far into solving problems such as highway visibility and avoid common accidents associated with too much elephant grass along Cameroon motorways. In recommending elephant grass as mulch material it will be necessary to study its allelochemical potentials as well as manure quality.

- Since different growth stages produced different results with the different mulches, further research should to investigate the growth stage and the appropriate mulch to use for best results may not be a wrong recommendation.

- One and if not major use of Mulches in agriculture is to conserve soil moisture especially in rainfed areas like Nfonta. This research like others have shown tIt is recommended that this research be repeated and include the effects of the four mulches on shat mulching is a a way to boost crop yield. This research should be repeated with main objective to study the effects of the four Mulches on soil properties especially those affecting moisture.

\section{References}

Ajibola, A., Modupeola, T., \& Adenuga, A. (2014). Effect of different weed control practices on growth and yield of sesame in south-west Nigeria. Journal of Biological and Chemical Research, 31(2), 1093-1100.

Anonymous. (2008). Harmonization of wastelands/degraded lands datasets of India.Published by National Rainfed Area Authority (NRAA). Ministry of Agriculture, Government of India, 5, 66-67.

Beebe, S. E., Rao, I. M., Mukankusi, C., \& Buruchara, R. A. (2012). Improving resource use efficiency and reducing risk of common bean production in Africa, Latin America, and the Caribbean. In C. H. Hershey (Ed.), Eco-Efficiency: From vision to reality (p. 18). Centro Internacional de Agricultura Tropical (CIAT), Cali, CO. Retrieved from https://hdl.handle.net/10568/55608

Beshir, M. H. (2015). Improving Snap Bean (Phaseolus vulgaris L.) Production under Reduced Input Systems. A $\mathrm{PhD}$ Thesis submitted to University of Saskatchewan, Canada. pp. 24-72.

Carmichael, P. C., Shongwe, V. D., Masarirambi, M. T., \& Manyatsi, A. M. (2012). Effect of mulch and irrigation on growth, yield and quality of radish (Raphanus sativus L.) in a semi-arid sub-tropical environment. Asian Journal of Agricultural Sciences, 4(3), 183-187.

Edje, O. T., \& Ossom, E. M. (2009). Crop Science Handbook. Crop Production Department, Faculty of Agriculture. University of Swaziland.

FAO. (2012). FAOSTAT statistical database. Food and Agriculture Organization of the United Nations, Rome, Italy. Retrieved from https://www.fao.org

FAO. (2020). Fruit and vegetables - your dietary essentials. The International Year of Fruits and Vegetables, 2021, background paper, Rome. https://doi.org/10.4060/cb2395en

Freytag, G. F., \& Debouck, D. G. (2002). Taxonomy, distribution, and ecology of the genus phaseolus (Leguminosae-papilionoideae) in North America, Mexico and Central America. Botanical Research Institute of Texas (BRIT), Forth Worth, TX, USA. pp. 298. Retrieved from https://hdl.handle.net/10568/54291

Jodaugiene, D., Sinkeviciene, A., Pupaliene, R., Ninkovic, V., \& Kriauciuniene, Z. (2018). Allelopathic effect of organic mulches on vegetable germination and early development. Acta Sci. Pol. Hortorum Cultus, 17(3), 73-82. https://doi.org/10.24326/asphc.2018.3.7

Kaiser, C., \& Ernst, M. (2017). Snap Beans. CCD-CP-118. Lexington, KY: Center for Crop Diversification, University of Kentucky College of Agriculture, Food and Environment. Retrieved from http://www.uky.edu/ccd/sites/www.uky.edu.ccd/files/snapbeans.pdf

Kalima, S. P. (2013). Physiological responses of common bean (Phaseolus vulgaris L.) genotypes to water stress (MSc Thesis). University of Zambia, Lusaka. pp. 91.

Kimani, P. M. (2006). Snap beans for income generation by small farmers in east Africa [on line]. Centro Internacional de Agricultura Tropical (CIAT), Kampala, UG. pp. 2. Retrieved from https://hdl.handle.net/10568/70449 
Kwambe, X. M., Masarirambi, M. T., Wahome, P. K., \& Oseni, T. O. (2015). The effects of organic and inorganic mulches on growth and yield of green bean (Phaseolus vulgaris L.) in a semi-arid environment.

Manzini, S., Safiullah, M., Ahmed, S. U., \& Rahman, M. H. (1996). Effect of mulching on the growth and yield of Cabbage. Progressive Agriculture, 7(1), 15-19.

Molua, E. L., \& Lambi, C. M. (2007). The Economic Impact of Climate Change on Agriculture in Cameroon. Policy Research Working Paper No. 4364. World Bank, Washington, DC. Retrieved from https://openknowledge.worldbank.org/handle/10986/7362

Negash, A., Tulu, S., \& Getachew, E. (2018). Yield and Yield Components of Snap Bean (Phaseolus vulgaris L.) as affected by N and P Fertilizer Rates at Jimma, Southwestern Ethiopia. Adv Crop Sci Tech, 6(3), 369. https://doi.org/10.4172/2329-8863.1000369

Nyambod, E. M. (2010). Environmental consequences of rapid urbanisation: Bamenda city, Cameroon. Journal of Environmental Protection, 1(1), 15-23. https://doi.org/10.4236/jep.2010.11003

Porch, T. G., Beaver, S. J., Debouck, G. D., Jackson, A. S., Kelly, D. J., \& Dempewolf, H. (2013). Use of wild relatives and closely related species to adapt common bean to climate change. Agronomy, 3(2), 433-461. https://doi.org/10.3390/agronomy3020433

Quamruzzaman, A. K. M., Islam, F., \& Mallick, S. R. (2021). Mulch Effect on Growth and Yield of Vine Vegetables. European Journal of Agriculture and Food Sciences, 3(1), 143-147. https://doi.org/10.24018/ejfood.2021.3.1.244

Tamfuh, A. P., Tsozué, D., Tita, M. A., Boukong, A., Tchinda, N. R., Ntangmo, T. H., \& Mvondo, Z. A. D. (2017). Effect of Topographic Position and Seasons on the Micronutrient Levels in Soils and Grown Huckleberry (Solanum scabrum) in Bafut (North-West Cameroon). World Journal of Agricultural Research, 5(2), 73-87. https://doi.org/10.12691/wjar-5-2-3

Tarara, J. M. (2009). Book Review: Plant Growth and Climate Change. Hort Science, 43(23), 23-99.

Teame, G., Tsegay, A., \& Abrha, B. (2017). Effect of Organic Mulching on Soil Moisture, Yield, and Yield Contributing Components of Sesame (Sesamum indicum L.). International Journal of Agronomy, 2017. https://doi.org/10.1155/2017/4767509

Unique-Kulima Deutsche Gesellschaft für Internationale Zusammenarbeit (GIZ GmbH). (2017). Agricultural adaptation: Six categories of good practices and technologies in Africa - Project Report. Retrieved from http://www.nepad.org/system/files/Implementation\%20Strategy\%20Report\%20English

Widuri, I. L., Lakitan, B., Sodikin, E., Hasmeda, M., Meihana, M., Kartika, K., \& Siaga, E. (2018). Shoot and Root Growth in Common Bean (Phaseolus vulgaris L.) Exposed to Gradual Drought Stress. Journal of Agricultural Science, 40(3), 442-452. https://doi.org/10.17503/agrivita.v40i0.1716

\section{Copyrights}

Copyright for this article is retained by the author(s), with first publication rights granted to the journal.

This is an open-access article distributed under the terms and conditions of the Creative Commons Attribution license (http://creativecommons.org/licenses/by/3.0/). 